\title{
GENDER PERSPEKTIF INTERPRETASI TEKS DAN KONTEKSTUAL
}

\author{
Akmaliyah $^{1)}$, Khomisah $^{2)}$ \\ Fakultas Adab dan Humaniora UIN Sunan Gunung Djati Bandung \\ 1)akmaliyah@uinsgd.ac.id \\ 2)khomisah@uinsgb.ac.id
}

\begin{abstract}
This article is intended to provide an overview of how the construction of gender biases in the perspective of interpretation and reality has long been institutionalized and legal in the midst of society, both covering methods of interpreting gender biases, interpreting gender-biased verses, as well as textual and contextual. This discussion certainly aims as ventilation and free space in the interpretation of the verses of the Qur'an as the contextuality of Islamic teachings to be in harmony with the development of the times for contemporary mufflers. This study uses descriptive qualitative methods within the scope of library research. The results of this study indicate that the construction of gender biases in the perspective of interpretation and reality produces an order in which men are always imaged in a superior position almost in Muslim history, while women are always in a weak image supported by the interpretation of the verses of the Qur'an' an and al-Hadith which are literal, narrative, and legal misogynist.
\end{abstract}

Keywords: Gender Bias, Interpretation Perspective, and Reality Perspective

\begin{abstract}
ABSTRAK
Artikel ini dimaksudkan untuk memberikan gambaran bagaimana konstruksi bias gender dalam perspektif tafsir dan realitas yang telah sekian lama melembaga dan legal di tengah-tengah masyarakat, baik yang meliputi metode penafsiran bias gender, penafsiran ayat-ayat bias gender, serta tekstual dan kontekstual. Pembahasan ini tentunya bertujuan sebagai ventilasi dan ruang gerak yang bebas dalam interpretasi ayat-ayat Al-Qur'an sebagai kontekstualitas ajaran-ajaran Islam agar selaras dengan perkembangan zaman bagi para muffasir kontemporer. Penelitian ini menggunakan metode yang bersifat deskriptif kualitatif dalam lingkup kajian pustaka (library research). Hasil penelitian ini menunjukan babwa konstruksi bias gender dalam perspektif penafsiran dan realita menghasilkan tatanan di mana laki-laki selalu dicitrakan dalam posisi yang unggul hampir dalam sejarah Muslim, sementara perempuan selalu berada dalam citra yang lemah dengan didukung oleh penafsiran ayat-ayat Al-Qur'an dan al-Hadits yang bersifat misoginis secara harfiah, naratif, dan legal.
\end{abstract}

Kata Kunci: Bias Gender, Perspektif Realita, Perspektif Tafsir 


\section{PENDAHULUAN}

Masalah gender menjadi sangat menarik ketika dikaitkan dengan wacana Islam, yang secara efektif merupakan bagian dari berbagai perubahan sosial, budaya dan bahkan politik. Berbagai upaya telah dilakukan untuk mengembangkan masalah dari dekonstruksi perbendaharaan khazanah Islam hingga upaya rekonstruksi. Salah satu poin utama dari studinya adalah masalah hubungan antara pria dan wanita.

Dalam konteks hubungan ini, laki-laki selalu dianggap sebagai pengendali peran publik, dan perempuan dipandang sebagai dominator dan penentu peran domestik. Oleh karena itu sehingga diasumsikan bahwa keduanya memiliki wilayah realisasi diri yang berbeda. Menurut Fakih (1999: 74), pemisahan budaya ini adalah warisan budaya dan budaya masyarakat primitif serta masyarakat pertanian dan masyarakat modern. Di sisi lain, ditemukan bahwa banyak pemahaman tentang teks yang dapat memperkuat konstruksi budaya dan bahkan membantu melanggengkannya. Dokumen antara teks-teks itu terungkap dalam budaya patriarki Arab, sehingga interpretasinya selalu spesifik gender. Sementara dalam pendekatan lain ada banyak teks yang sebenarnya mendukung kesetaraan antara pria dan wanita. Dari konteks ini dapat dipahami bahwa konsep-konsep hubungan laki-laki dan perempuan muncul dan berkembang berdasarkan hasil memahami teks dan konstruksi budaya, sehingga berbagai bentuk realitas sekarang dapat ditemukan.

Keadilan gender telah menjadi keharusan di zaman ini. Setidaknya upaya menggagas keadilan gender telah dilakukan melalui berbagai seminar dan kajian di hampir seluruh belahan dunia. Di Indonesia misalnya, ia juga telah diinisiasi melalui keberadaan lembaga pemerintah yang sekarang disebut KPP-PA (Kementerian Pemberdayaan Perempuan dan Perlindungan Anak), di berbagai perguruan tinggi lahir lembaga PSGA (Pusat Studi Gender dan Anak), yang kesemuanya itu turut andil dalam pembahasan keadilan gender. Namun terlepas dari itu semua, pemahaman atas teks-teks keagamaan yang mengabaikan perspektif gender, masih menjadi konflik dan wacana publik.

Islam lahir dalam konteks budaya patriarkal. Budaya patriarkal adalah budaya yang mencakup pemahaman bahwa laki-laki adalah garis utama dalam masyarakat. Karena mengadopsi sistem patriarkal dan penafsirnya lebih jantan, penafsiran ayat-ayat dalam teks suci lebih untuk pria daripada wanita. Oleh karena itu, hasil interpretasinya pun dapat menjadi salah satu kontribusi untuk munculnya problematika bias gender.

Al-Qur'an adalah kitab suci yang sangat terbuka dengan interpretasi yang berbeda. Dari era 
klasik hingga era kontemporer, Al-Qur'an telah banyak melahirkan tafsiran dengan gaya dan pendekatan yang berbeda. Dari sudut pandang penafsiran itu kemudian melahirkan corak aliran penafsiran bi a-ra'yi dan penafsiran bi al-maur adalah. Yang pertama adalah gaya interpretasi yang menekankan rasionalitas, dan yang kedua adalah gaya interpretasi berdasarkan pada hadits. Pendekatan interpretasi Al-Qur'an juga sangat berbeda dan berkisar dari pendekatan tekstual ke pendekatan interdisipliner. Gaya dan pendekatan berbeda dalam penafsiran Al-Qur'an mengindikasikan pada hasil penafsiran yang berbeda pula.

Ayat-ayat gender dalam Al-Qur'an termasuk dalam bagian ayat-ayat yang telah ditafsirkan oleh para mufassir. Ayat-ayat gender adalah ayat-ayat dalam Al-Qur'an yang berbicara tentang status dan peran laki-laki dan perempuan. Dan kata kunci yang dapat dipegang untuk mengetahui ayat-ayat gender ialah semua istilah yang sering digunakan untuk menyebut laki-laki dan perempuan (Umar, 2002: 118). Jika tafsir ayat-ayat gender dilakukan dengan corak bi al-ma'tsur dan pendekatan tekstual, maka unsur-unsur budaya yang melahirkan teks atau dialektikan antara teks dan konteks akan diabaikan karena mufassir dalam hal ini berpegang pada kaedah: "yang dijadikan pegangan adalah keumuman lafadz, bukan kekhususan sebab" (Umar, 1999: 281).

Pendekatan tekstual dianggap tidak memadai oleh beberapa mufassir kontemporer karena mereka memeriksa makna ayat-ayat Al-Qur'an yang kaya dan kompleks. Mereka berdebat mengapa bahasa Arab, yang digunakan dalam Al-Qur'an, adalah bahasa yang memiliki hubungan dialektis dengan kondisi objektif, kapan dan di mana Al-Qur'an diturunkan. Berbeda dengan pendekatan tekstual, pendekatan multidisiplin untuk menafsirkan ayat-ayat gender mempertimbangkan status dan peran perempuan dan laki-laki yang dibahas dalam Al-Qur'an dari perspektif yang berbeda, termasuk sosial-budaya, sosial-historis, dan filosofis.

Tujuan utama kitab suci Al-Qur'an adalah untuk membebaskan orang dari berbagai bentuk diskriminasi dan penindasan, termasuk diskriminasi seksual. Jadi jika ada interpretasi yang mengarah pada nilai ketidakadilan, maka interpretasi tersebut harus diperiksa dan ditafsirkan kembali (reinterpretasi). Hal ini dikarenakan interpretasi pada dasarnya merupakan kunci untuk membuka mutiara hikmah yang tersimpan secara apik di dalam Al-Qur'an, yang diturunkan kepada umat manusia dan semua umur dalam segala zaman.

Menurut al Zarqani, dalam menafsirkan Al-Qur'an yang tepat dan sejalan dengan perkembangan dan kemajuan dunia modern adalah tafsir yang bercorak rasional, yang sering disebut sebagai Tafsir bi al Ra'yi atau bisa juga disebut sebagai Tafsir bi al Ijtihad (al-Zarqani, 1988: 49). Bahkan, menurut Ali Asghar Engineer (1994: 16), orang harus bisa memahami ayat-ayat yang 
kontekstual, artinya paham ketika menafsirkan ayat yang terkait dengan gender dalam konteks masyarakat termasuk di dalamnya memahami tentang status perempuan .

Namun kenyataannya adalah bahwa dalam hal penafsiran agama yang spesifik gender menghadapi tantangan besar. Jika interpretasi perempuan selalu didefinisikan oleh konsep fiqh, perempuan dianggap lebih buruk daripada interpretasi yang mengandung prasangka misoginis. Mungkin ada beberapa alasan untuk ini, sebagaimana yang diungkapkan oleh Aminah Wadud (2001: 85) berikut:

1. Pemahaman terhadap pengertian gender dan seks dalam mendefinisikan peran seringkali belum pas.

2. Metode penafsiran yang selama ini digunakan, masih banyak mengacu pada pendekatan tekstual, bukan kontekstual; sebagai konsekuensi qaidah ushul yang biasa dijadikan pegangan jumhur ulama tafsir (al ibrah bi umum al lafdri, la bi khusus as sabab).

3. Umumnya mufassir adalah kaum laki-laki.

4. Banyak dikesankan bahwa kitab suci Al-Qur'an banyak memihak laki-laki dan mendukung sistem patriarkhi, yang oleh kalangan feminis dipandang bisa merugikan perempuan.

5. Pengaruh kisah Israiliyat yang berkembang luas di kawasan Timur Tengah.

Bias gender tidak hanya terjadi dalam memahami atau menafsirkan ayat-ayat, melainkan juga muncul dalam pemahaman hadis Nabi Muhammad SAW. Bahkan, bias gender juga ditemukan dalam interpretasi banyak literatur Islam klasik (kitab kuning), terutama dalam interpretasi kitab-kitab fiqh yang pada umumnya sering dianggap mutlak kebenarannya. Oleh sebab itu, maka kajian interpretasi atas literatur khazanah Islam memerlukan formula baru atau sinkronisasi kajian tafsir dan realita atau tekstual dan kontekstualisasi. Bersadarkan pemaparan di atas, maka tulisan ini berusaha membahas konstruksi bias gender dalam perspektif tafsir dan realita, baik dalam metode penafsiran bias gender, penafsiran ayat-ayat bias gender, serta tekstual dan kontekstual, agar menjadi acuan dalam interpretasi khazanah Islam menggunakan pendekatan multidisipliner.

\section{METODE}

Penelitian ini menggunakan metode yang bersifat deskriptif kualitatif. Metode deskriptif dapat diuraikan sebagai prosedur pemecahan masalah yang diselidiki dengan menggambarkan keadaan objek penelitian pada saat sekarang berdasarkan fakta yang tampak atau sebagaimana 
adanya. Metode ini juga bertujuan untuk melukiskan secara sistematis fakta atau karakteristik objek penelitian secara faktual dan cermat. Dalam penelitian ini, metode tersebut digunakan untuk mendeskripsikan dan memaparkan konstruksi penafsiran bias gender perspektif tafsir dan realita.

Penelitian kualitatif menggunakan analisis data secara induktif, yang salah satu alasannya adalah karena proses induktif lebih dapat menemukan kenyataan-kenyataan ganda sebagaimana yang terdapat di dalam data, dapat menemukan pengaruh bersama yang mempertajam hubunganhubungan, dan dapat memperhitungkan nilai-nilai secara eksplisit sebagai bagian dari struktur analitik. Dengan menggunakan analisis secara induktif, berarti pencarian data bukan dimaksudkan untuk membuktikan hipotesis yang telah dirumuskan sebelum penelitian diadakan. Analisis ini lebih merupakan pembentukan abstraksi berdasarkan bagian-bagian yang telah dikumpulkan, kemudian dikelompokan. Jadi, penyusunan teori di sini berawal dari bawah ke atas, yaitu dari sejumlah bagian yang banyak data yang dikumpulkan dan yang saling berhubungan. Jika peneliti merencanakan untuk menyusun teori, arah penyusunan tersebut akan menjadi jelas sesudah data dikumpulkan. Jadi, peneliti dalam hal ini menyusun atau membuat gambaran yang makin jelas, sementara data dikumpulkan dan bagian-bagiannya diuji. Dalam hal ini peneliti tidak berasumsi bahwa sudah cukup yang diketahui untuk memahami bagian-bagian penting sebelum mengadakan penelitian (Moleong, 2007: 6-7).

\section{HASIL PENELITIAN}

\section{Metode Penafsiran Bias Gender}

Beberapa mufasir menafsirkan teks-teks suci dari ayat-ayat Al-Qur'an menggunakan metode penafsiran bil ma'ur (penafsiran berdasarkan pada Al-Quran, Hadits atau ijtihad Sahabat) dan metode penafsiran bil ra'yi (penafsiran Al-Quran berdasarkan pada logic of thinking based). Interpretasi yang menggunakan kedua metode ini terkadang masih bias gender. Untuk menghindari ini, perlu ditafsirkan kembali atau diperbarui dengan harapan mendapatkan kebenaran lebih dekat.

Metode tafsir paling dominan dalam sejarah intelektual dunia Islam ialah metode tablili, suatu metode penafsiran Al-Qur'an yang menganalisis secara kronologis dan memaparkan berbagai aspek yang terkandung di dalam ayat-ayat Al-Qur'an, sesuai dengan urutan bacaan yang terdapat di dalam Mushaf Utsmani (al-Zarqani, 1988: 51). Metode ini juga biasa disebut metode Tajzi karena pembahasannya didasarkan pada beberapa bagian Al-Qur'an. Sebagai metode jumhur ulama, metode ini sangat dominan pengaruhnya terhadap masyarakat. Ciri khas dari metode ini adalah menempatkan teks sebagai pusat perhatian. Ketika menganalisis suatu kasus, fokusnya langsung 
pada teks yang ada, karena konsep perintah dan larangan dalam Al Qur'an umumnya menggunakan bentuk umum, meskipun ini diungkapkan untuk alasan tertentu. Jumhur ulama menetapkan aturan bahwa "apa yang diadakan adalah generalitas Lafadz". Jika ada kasus, perhatian utama adalah seperti apa bentuk teks untuk kasus tersebut, bukan tentang kasusnya.

Berbeda dengan metode tematis (mawdlu’) yang didefinisikan oleh M. Quraish Shihab (1992: 110) sebagai "tafsir yang menetapkan suatu topik tertentu, dengan jalan menghimpun seluruh atau sebagaian ayat-ayat, dari beberapa surat, yang berbicara tentang topik tersebut, untuk kemudian dikaitkan satu dengan lainnya, sehingga pada akhirnya diambil kesimpulan secara menyeluruh tentang masalah tersebut menurut pandangan Al-Qur'an". Metode ini lebih berfokus pada apa yang umumnya dikatakan ayat-ayat Al-Quran tentang suatu subjek. Saat menganalisis suatu kasus, para pendukung teori ini juga memperhatikan keberadaan teks. Tidak hanya berfokus pada satu teks dalam kelompok ayat, tetapi semua ayat yang membahas kasus dianalisis dengan cermat, termasuk menganalisis penyebab dari ayat-ayat tersebut, yang mengarah pada kesimpulan. Sebagai contoh penafsiran QS. An-Nisa ayat 3 berikut:

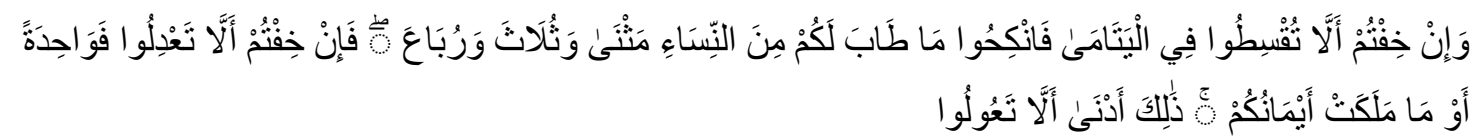

Artinya: "Dan jika kamu takut tidak akan dapat berlaku adil terhadap (bak-bak)) perempuan yang yatim (bilamana kamu mengawininya), maka kawinilah wanita-wanita (lain) yang kamu senangi: dua, tiga atau empat. Kemudian jika kamu takut tidak akan dapat berlaku adil, maka (kawinilah) seorang saja, atau budak-budak yang kamu miliki. Yang demikian itu adalah lebih dekat kepada tidak berbuat aniaya".

Ayat ini menggunakan shigah umum, yaitu menggunakan kata ganti jamak (فَانْكِحُو ا, أَيْمَانُكُمْ ,

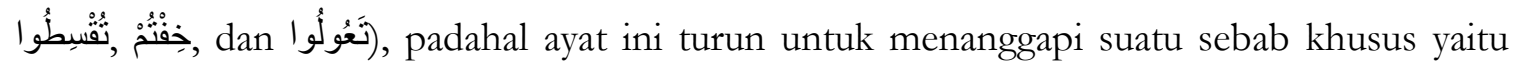
kasus 'Urwah ibn Zubair' sebagaimana hadits yang diriwayatkan Bukhari yang bersumber dari A'isyah, bahwa ia mempunyai seorang anak yatim yang hidup di dalam pengawasannya. Selain cantik, anak yatim itu juga memiliki harta sehingga "Urwah bermaksud mengawininya, maka ayat ini menjadi petunjuk bagi 'Urwah dalam melangsungkan niatnya (al-Shabuni, 1981: 464).

Metode tablili menyimpulkan bahwa teks ayat tersebut di atas mengizinkan poligami, yaitu seorang laki-laki boleh kawin lebih dari satu sampai empat, asal yang bersangkutan mampu berlaku adil. Akan tetapi metode mawdlu'i bisa menyimpulkan lain, karena adanya ayat di 
tempat lain yang seolah-olah memustahilkan syarat adil itu dapat dilakukan manusia. Ayat tersebut ialah QS. An-Nisa ayat 129:

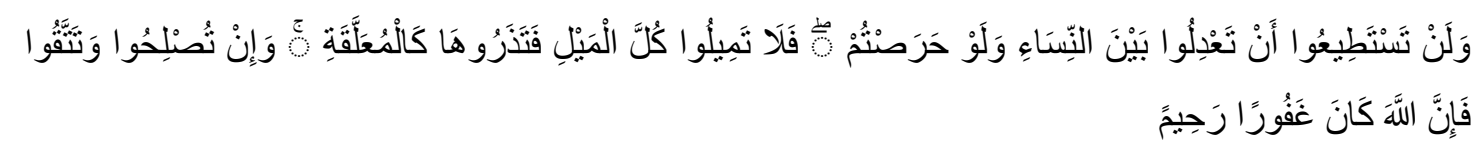

Artinya: "Dan kamu sekali-kali tidak akan dapat berlaku adil di antara isteri-isteri(mu), walaupun kamu sangat ingin berbuat demikian, karena itu janganlah kamu terlalu cenderung (kepada yang kamu cintai), sehingga kamu biarkan yang lain terkatung-katung. Dan jika kamu mengadakan perbaikan dan memelihara diri (dari kecurangan), maka sesunggubnya Allab Maba Pengampun lagi Maha Penyayang”.

Ayat ini dapat diartikan menolak poligami atau paling tidak lebih memperketat pelaksanaan poligami. Syarat poligami adalah kesanggupan untuk berlaku adil, sementara ayat ini menegaskan

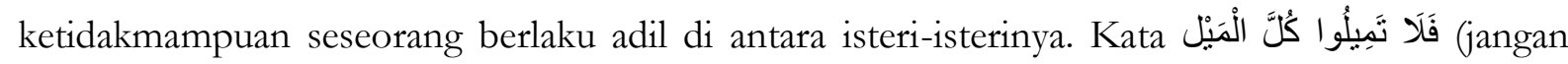
kalian terlalu cenderung pada setiap kecenderungan) dalam ayat di atas, difahami sebagian mufassir sebagai penolakan pemustahilan berpoligami.

Menurut al-Maraghi, bagian dari ayat tersebut tampaknya menarik bagi mereka yang tidak dapat melakukan keadilan, sementara mereka yang mampu melakukan keadilan sendiri tidak memiliki potensi untuk ayat ini. Jadi bagian ayat ini berisi penjelasan dari bagian ayat sebelumnya yang menghilangkan kemampuan untuk berlaku adil pada wanita dan dengan demikian menyangkal ketidakmungkinan poligami. Bagaimanapun, metode Mawdlu'i terhadap poligami lebih ketat daripada metode Tablili.

Ayat pertama datang ketika perang Uhud baru saja dimulai, dalam peristiwa ini tentara Islam menderita kekalahan. Dalam suasana perang orang dapat membayangkan bahwa populasi lakilaki relatif kecil, tetapi di sisi lain populasi janda dan anak yatim semakin meningkat, sehingga tidak perlu dikatakan bahwa poligami dibenarkan pada masa-masa awal. Ada sebuah sumber yang mengatakan bahwa populasi Muslim memiliki lebih banyak wanita daripada pria di masa-masa awal Islam. Di antara 500 orang hanya terdapat seperlima laki-laki yang dapat menggunakan senjata. Selebihnya adalah perempuan dan anak-anak (Watt, 1968: 3). Kalau populasi yang kecil ini kalah lagi dalam peperangan, maka sedah barang tentu poligami bisa menjadi salah satu solusi dalam menyelesaikan masalah-masalah umat.

Untuk memahami ayat-ayat gender dalam Al-Qur'an membutuhkan metode yang yang komprehensif, tidak hanya metode yang dikenal dalam sejarah Al-Qur'an, tetapi juga harus merujuk pada metode studi teks lainnya secara menyeluruh. Hal ini sebagaimana dikemukakan 
oleh Fathurrahman (2010: 87) bahwa untuk mendapatkan interpretasi yang faktual diperlukan metode penafsiran Al-Qur'an yang holistik, yaitu penafsiran Al-Qur'an secara keseluruhan dan sesuai dengan model hermeneutik yang membedakan unsur normatif dan kontekstual.

Dalam metode penafsiran bias gender juga cukup dipengaruhi oleh riwayat Israiliyyat. Pengutipan kisah Israeliliyyat ke dalam kitab-kitab tafsir $M u^{\prime}$ tabar dikatakan untuk memberikan penjelasan (Mubayyin) tentang beberapa ayat dari Al-Qur'an. Namun, hal ini kadang-kadang menyebabkan kesulitan dalam mengidentifikasi orisinalitas ajaran Islam dalam tradisi masyarakat. Penafsiran ayat-ayat gender dalam Al-Qur'an menggunakan banyak "alat" tradisi Yahudi-Kristen, karena "hukum adat" (living law) yang berlaku di masyarakat Madinah -tempat ayat-ayat tradisional dalam hukum Al-Qur'an- sangat dipengaruhi oleh tradisi Yahudi.

Contoh dari kisah Israiliyyat dalam penafsiran Al-Qur'an adalah sejarah asal-usul peristiwa perempuan. Perjanjian Lama menceritakan kisah-kisah yang umumnya dimaksudkan untuk memberi perempuan citra negatif, seperti interpretasi feminis tentang kehadiran perempuan untuk memuaskan kebutuhan pria. Perempuan dipandang sebagai ciptaan kedua dan penyerahan laki-laki karena mereka diciptakan dari tulang rusuk laki-laki. Wanita dianggap bertanggung jawab atas drama kosmik yang membuat Adam jatuh ke bumi, itulah sebabnya wanita harus mengambil lebih banyak risiko dalam konsep dosa keturunan. Ayat-ayat ini dijelaskan secara rinci dalam Talmud, sebuah buku yang meneliti ayat-ayat yang terkandung dalam Perjanjian Lama (Umar, 1999: 167).

Kisah-kisah Israiliyyat dapat ditemukan dalam penjelasan beberapa kisah Al-Qur'an, seperti komentar tentang Ya'juj dan Ma'juj (ayat Surat Al-Anbiya 96), Dzu al-Qarnain (ayat Surat AlKahfi 83), Ashhab al-Kahf (Surat Al-Kahf ayat 9), kisah beberapa Nabi dan Fir'aun. Penggunaan cerita Israeliliyyat untuk memahami ayat-ayat Al-Qur'an tidak selalu dianggap negatif. Hanya saja masalahnya adalah memperluas keaslian cerita yang dijadikan referensi. Jika rujukannya adalah cerita-cerita yang terkandung dalam Talmud, masalah timbul karena, seperti yang dijelaskan di atas, Talmud berisi banyak cerita rakyat Babilonia (Umar, 1999: 268).

Pengenalan tradisi klasik masyarakat Babilonia yang terkait dengan mitos ini jelas akan mengarah pada bias gender karena mitos tersebut sangat bias pada wanita. Cerita rakyat tentang perempuan di Timur Tengah memiliki banyak kesamaan yang cenderung mendiskreditkan perempuan. Tidak mengherankan, komentar yang memperkenalkan kisah-kisah Islam menemukan banyak interpretasi yang mendiskreditkan perempuan.

\section{Penafsiran Ayat-Ayat Bias Gender}


Penafsiran ajaran agama perspektif gender adalah suatu keharusan untuk menjaga keadilan gender. Interpretasi bias gender sebagai gambaran dominasi pemikiran patriarkal telah memarginalkan dan menutup jalan bagi pertumbuhan pemikiran yang dapat terlibat dalam berbagai perjuangan dalam pemikiran Islam. Ini membuat produk pemikiran gender semakin tak tertandingi. Sayangnya, transisi untuk mengembangkan interpretasi perspektif gender tidak mudah. Produk interpretasi bias gender telah menjadi kenyataan kebenaran yang hampir semua Muslim percayai. Mereka bahkan tidak memperhatikan efek dari produk-produk interpretif ini, yang seringkali mengarah pada kekerasan terhadap perempuan. Produk dari interpretasi ini juga mewujudkan otoritas dari pemegang interpretasi bias gender yang tidak boleh dipertanyakan.

Perkembangan interpretasi perspektif gender dipandang sebagai upaya untuk menentang kebenaran Islam yang telah mereka yakini selama bertahun-tahun dan untuk melemahkan pihakpihak terkait yang telah menjadi panutan selama bertahun-tahun. Untuk membangun interpretasi sederhana, dimungkinkan untuk memahami analisis gender dan menerapkannya pada interpretasi yang mampu membedakan antara seks dan gender. Seks adalah gender, sedangkan gender didasarkan pada konstruksi sosial-budaya, yang memiliki karakteristik perubahan dan dapat menjadi sifat, peran dan karakteristik setiap orang, tanpa memandang jenis kelamin seksual.

Interpretasi, perspektif, ras, kelompok sosial, dan budaya yang berbeda sangat sulit diposisikan sebagai sumber daya untuk membangun negara multikultural. Banyak alasan untuk interpretasi berbeda dari ajaran agama yang berfungsi sebagai alasan untuk menilai dan menyerang kelompok yang berbeda. Dalam aspek lain, interpretasi yang berbeda dari ajaran agama sebenarnya digunakan sebagai barang politik, yang tidak sedikit memicu konflik sosial dan kekerasan. Yang menarik, mereka yang melakukan kekerasan atas nama agama adalah pria. Karena mereka didasarkan pada formulasi epistemologis dan pada perspektif prasangka keagamaan yang didistorsi oleh laki-laki, keanekaragaman juga sering menggunakan logika yang tidak terkendali dan berani untuk memperjuangkan kebenaran tentang apa yang diperjuangkan seseorang. Oleh karena itu penafsiran agama yang dimonopoli oleh orang-orang yang kejam, misalnya ayat-ayat tentang jihad yang sering ditafsirkan secara fisik, dan yang lain tidak biasa. Bisa jadi karena pengaruh maskulinitas atau didorong oleh psikologi pria.

Sejarah panjang agama sebenarnya adalah sejarah manusia dalam arti luas. Pemahaman ini mengacu pada potret keragaman manusia yang dengannya kehadiran interpretasi agama yang dihasilkan adalah produk manusia. Produk-produk wanita tampaknya menghilang dan dihilangkan dari domain pria. Oleh karena itu, referensi cara memahami ajaran agama, cara 
berpikir, memecahkan masalah dan menangani masalah sosial-agama adalah cara pria. Ini adalah fakta yang harus direspon secara bersama.

Penyebaran hooliganisme ("premanisme") agama selama bertahun-tahun disebabkan oleh kegagalan metode keagamaan pria tanpa evaluasi dan kritik. Ketika Huntington mengklaim bahwa konflik pada saat itu adalah salah satu dari konflik tersebut karena benturan peradaban, dapat dikatakan, dalam konteks hooliganisme agama, bahwa itu adalah "bentrokan antara interpretasi pria". Di mana produk interpretasi selalu berkaitan dengan pemahaman fisik dan perilaku yang dibangun oleh logika pria. Ini adalah kecenderungan budaya patriarki yang menghilangkan kematangan pemikiran.

Tetapi ini tidak berarti bahwa produk dari ide-ide wanita berarti sempurna. Tetapi ini merupakan gambaran untuk menunjukkan bahwa agama kita kering dari dialog antara sistem pemikiran, baik agama, kelompok, lintas interpretasi dan lintas jenis kelamin. Tampaknya sulit bagi komunitas agama kita untuk mengubah tradisi ini. Gagasan, pemikiran, dan pemahaman perempuan yang benar-benar dapat diperhitungkan ketika mengevaluasi interpretasi agama sering tidak dipertimbangkan dan tidak lazim bagi gagasan cerdas perempuan untuk diposisikan terhadap hal-hal absolut agama, seperti halnya pemahaman. agama berasal dari wahyu yang jelas.

Tentunya sudah saatnya bagi kita untuk mengembangkan budaya religius dialogis, terutama di antara kelompok-kelompok agama internal, agar tidak hidup di pasar dengan nilai mono, perspektif mono, monokultur, dan interpretasi mono. Karena cara pandang yang dipaksakan untuk selalu homogen tidak selalu mendatangkan berkah dan manfaat, tetapi tidak jarang melakukan hal sebaliknya, yaitu membawa bencana. Sudah bukan waktunya lagi bagi pria atau wanita untuk menetapkan otoritas agama atas perbedaan jenis kelamin, karena keberadaan agama tidak berlaku untuk satu jenis kelamin, tetapi untuk semua orang yang membutuhkan ide moral agama. Bahwa kita bisa menjadi bagian dari mereka yang bisa menyebarkan cinta dan kedamaian.

Dalam tafsir dan realita terkadang ada teks yang terdengar bagus untuk wanita, tetapi sebaliknya suara yang tidak menguntungkan terhadap posisi wanita, beberapa kesimpulan dapat ditarik dalam kedua agama:

Pertama, adanya perbedaan yang jelas antara pria dan wanita. Pria mendapat manfaat lebih dari wanita. Ini disebabkan oleh budaya yang mengelilingi tempat wahyu. Ratna Megawangi (dalam Nadjib, 2008: 32) berpendapat bahwa patriarkhi benar-benar ada dalam Islam dengan memberi contoh bahwa suami adalah kepala keluarga (Al-Quran 2:228) dan laki-laki adalah pemimpin dan penjaga kaum perempuan (Al-Quran 3:34). Kitab Suci memberikan peran yang 
berbeda untuk dua jenis kelamin yang berbeda. Pertanyaannya adalah apakah peran ini ditafsirkan sebagai diskriminasi atau sebagai pembagian kerja yang wajar. Pemahaman ini tentunya bisa sangat relatif, jika melihatnya dengan kacamata modern, bisa mengatakan itu diskriminatif, tetapi jika dipahami pada saat itu, perlindungan perempuan sebenarnya diberikan oleh agama.

Kedua, persoalan penafsiran juga merupakan penyebab utama ketidaksempurnaan dalam memahami teks suci, tetapi juga sangat penting untuk mengenali bahwa tidak akan pernah ada pemahaman yang benar-benar sempurna dari teks suci. Pemahaman ini relatif tergantung pada waktu. Pendapat Tetullianus, Ambrogio, Lutero dan Calvino tentang perempuan sangat terkait dengan semangat penafsiran zamannya, oleh karena itu dari perspektif zaman kita ketika perjuangan untuk kesetaraan gender adalah salah satu interpretasi utama para bapak-bapak gereja tampaknya sangat diskriminatif. Tentu saja, dalam semangat era lain, kita kemudian harus berani membaca dan mengevaluasi kembali pemahaman agama kita, kalau tidak kita akan mengalami apa yang disebut Cak Nur "Jumud" (tertinggal). Untuk alasan ini, pemahaman dinamis, progresif, dan komprehensif dari teks-teks suci adalah penting.

\section{Tekstualitas dan Kontekstualitas}

Perbedaan peran antara laki-laki dan perempuan dalam masyarakat secara umum dapat dikategorikan dalam dua kategori besar: Pertama, teori nature, yang menyatakan bahwa perbedaan peran laki-laki dan perempuan ditentukan oleh faktor biologis. Menurut teori ini, sederet perbedaan biologis antara laki-laki dan perempuan menjadi faktor utama dalam penentuan peran sosial kedua jenis kelamin. Kedua, teori nurture, yang mengungkapkan bahwa perbedaan peran sosial lebih ditentukan oleh faktor budaya. Menurut teori ini pembagian peran laki-laki dan perempuan dalam masyarakat tidak ditentukan oleh faktor biologis, melainkan dikonstruksikan oleh budaya masyarakat (Umar, 1999: 4-7).

Pemahaman ilmiah dan kultural terhadap perbedaan jenis kelamin tersebut menimbulkan perdebatan panjang, termasuk di kalangan ilmuwan-teolog dan feminis. Mereka memberikan andil penting dalam wacana ini karena penafsiran-penafsiran mereka terhadap kitab suci merujuk kepada kondisi objektif lingkungan masyarakat di mana mereka berada. Tidak sedikit penafsiran mereka yang membenarkan konstruksi budaya yang hidup di dalam masyarakat. Namun sebaliknya, tidak sedikit konstruksi budaya dibangun di atas pemahaman kitab suci, misalnya persepsi Al-Qur'an terhadap tiga hal pokok tentang perempuan: Pertama, tujuan penciptaan perempuan untuk melengkapi kebutuhan laki-laki (Adam) di Surga. Pemahaman semacam ini mengesankan bahwa perempuan hanyalah pelengkap dan diciptakan untuk melayani kebutuhan 
laki-laki. Kedua, perempuan diciptakan dari tulang rusuk laki-laki. Analisis semacam ini mengesankan perempuan subordinat. Ketiga, perempuan sebagai penyebab jatuhnya manusia dari surga ke bumi. Hal ini mengesankan perempuan sebagai penyebab dosa warisan. Ketiga pemahaman tersebut membentuk persepsi yang mengendap di alam sadar masyarakat sehingga mereka memandang bahwa perempuan memang tidak pantas disejajarkan dengan laki-laki (Hidayatullah, 2015: 5-7).

Dalam pada itu, konsep gender (relasi laki-laki dan perempuan) dalam Islam masih menjadi perdebatan di kalangan umat Muslim. Sebagian kalangan berpendapat bahwa gender dalam Islam tidak ada masalah, dan sebagian yang menganggapnya ada masalah dan pandangan status quo tentang gender sudah saatnya digugat (Kadarusman, 2005: 4-5). Bila dicermati, pangkal perbedaan pendapat mereka sebenarnya terletak pada masalah interpretasi ayat. Karena itu, persoalan krusial yang perlu dikaji adalah menimbang perspektif "ke-Islam-an" terhadap kedua pendapat tersebut.

Penafsiran terhadap Al-Qur'an surat An-Nisa' ayat 4 seringkali dijadikan landasan justifikatif "superioritas" laki-laki (suami) atas perempuan (istri). Kata qawwamun dalam ayat tersebut dipahami terlepas dari advokasi Qur'anik lainnya tentang pembentukan kehidupan keluarga sehingga muncul klaim adanya relasi gender dalam lingkup domestik (Umar, 1999: 21). Padahal jika dihubungkan dalam kerangka pemahaman ideal moral Al-Qur'an tentang tujuan perkawinan, tata pergaulan suami-istri dan tanggung jawab keluarga, maka klaim di atas merupakan akibat dari pemahaman simplistik- parsialistik (menyederhanakan dan tidak menyeluruh) terhadap AlQur'an. Dominannya pola pemahaman semacam ini turut andil menutupi "keluhuran" Islam orisinal dengan "topeng” Islam historis. Lebih jauh dari pemahaman tersebut, Al-Qur'an semestinya ditangkap makna substansialnya sehingga selalu relevan dengan tantangan dan perkembangan zaman (Ilyas, 2004: 20).

Dalam budaya masyarakat patriarkhi, perempuan dianggap makhluk kedua, di mana perempuan tetap didominasi dan disubordinasi oleh sistem baik yang berdasar dari penafsiran berbagai teks keagamaan (Memissi dan Riffat Hassan, 1995: 95) maupun dari produk budaya masyarakat. Kekuasaan laki-laki mutlak dan sulit untuk dibatasi dengan argumen rasional. Pria selalu bisa menjadi sumber utama keluarga. Kekuatan laki-laki memperingatkan kesia-siaan perempuan, bahkan, mereka sering membuat suara utama laki-laki dalam keluarga. Arus utama dalam masyarakat patriarki menjadi sistem permanen. Perempuan telah menjadi bagian dari realitas penindasan dan dehumanisasi dalam masyarakat patriarki. 
Namun, perubahan sosial dan kebutuhan ekonomi menjadi bagian penting dari realitas sosial. Kekuatan manusia menjadi bagian yang tidak terpisahkan dari perubahan realitas dan budaya. Kekuatan realitas dihadapkan dengan teks dan interpretasi yang tidak berkembang dan secara konstan tidak bergerak oleh realitas yang semakin dinamis. Kekuatan dan kekuasaan laki-laki menjadi elemen dialogis antara kenyataan dan teks, sehingga tidak mengherankan dalam masyarakat bahwa pemahaman telah berkembang bahwa masyarakat dapat masuk ke ortodoksi dalam mengukur realitas.

Perempuan yang bekerja adalah kenyataan yang berlangsung lama dan telah menginjak periode yang tidak dapat dihitung. Dinamika sejarah perempuan berkaitan dengan ortodoksi, termasuk norma-norma dan ajaran agama, dan mengintegrasikannya ke dalam realitas masyarakat. Wanita yang bekerja (juga atas kemauannya sendiri) adalah hadiah yang dapat mereka syukuri, bahkan jika ada kekurangan "berbelanja di dapur" di rumah, wanita akan mencari dengan bekerja dalam profesi apa pun.

Dalam konsep ini, teks tidak dapat mewakili keseluruhan konteks. Sementara itu, teks harus ditafsirkan dari segi realitas dan budaya masyarakat. Meskipun penafsiran teks selalu memenangkan teks sebagai marji utama untuk memahami hukum (Islam), selalu ada pembenaran untuk realitas perempuan yang bekerja. Penafsiran realitas ini memungkinkan perempuan untuk bekerja dengan periode "pekerjaan" yang relatif panjang untuk pria.

\section{KESIMPULAN}

Kontekstualisasi penafsiran terletak pada kerangka metodologi penafsiran melalui berbagai pendekatan dalam menemukan rumusan konstruksi bias gender yang tidak hanya terbatas mengacu pada teks, tetapi juga tidak mengesampingkan realitas sosial-budaya sebagai sudut pandangnya atau melihat dan mempertimbangkan aspek kontekstualnya. Sehingga, interpretasi ayat-ayat kitab suci (baca: Al-Qur'an) itu hadir sebagai respon atas dinamika sosial-budaya yang terus mengalami laju perkembangan secara terus-menerus. Karena pada dasarnya suatu ajaran agama yang tersurat dalam kitab suci diciptakan semata-mata untuk menghantarkan pada tujuan kemaslahatan.

Kajian multidisipliner dalam interpretasi ayat-ayat Al-Qur'an hendaknya tidak mengesampingkan pada kajian hitoris, sosial, dan budaya, yang menjadi karakter khas yang terakumulasi dalam gagasan kontekstualisasi khazanah Islam. Pemahaman kontekstual sebagai pengembangan didasarkan atas keyakinan bahwa ajaran agama ataupun hukum harus dibaca dan 
dipahami berdasarkan kontesnya, sehingga ia tetap relevan dan menjadi tata aturan atau normanorma yang senantiasa diupgrade mengikuti perkembangan zaman. Karena alasan ini, Al-Qur'an menyentuh banyak hukum dan aturan, bukan sebagai penghalang bagi mobilitas dan peran, tetapi sebagai pedoman keselamatan. Oleh sebab itu, reinterpretasi atas ayat-ayat bias gender berarti merekonstruksi ulang maindset laki-laki dan perempuan sehingga mereka dapat secara proporsional mengeksploitasi peran dan potensi mereka dalam pemenuhan tatanan hak dan kewajibannya dalam kehidupan.

\section{DAFTAR PUSTAKA}

Engineer, Asghar Ali. 1994. Hak-hak Perempuan Dalam Islam, terj. Farid Wajdi. Yogyakarta: Bintang Budaya.

Fakih, Mansour. 1999. Analisi Gender \& Transformasi Sosial. Yogyakarta: Pustaka Pelajar.

Fathurrahman. “Al-Qur'an dan Tafsirnya dalam Perspektif Toshihiko Izutsu”, Tesis pada Sekolah Pascasarjana UIN Syarif Hidayatullah Jakarta, 2010.

Hidayatullah, Syarif. 2015. "Al-Qur'an dan Peran Publik Perempuan" dalam Gender dan Islam: Teks dan Konteks, ed. Waryono Abdul Ghafur dan Muh. Isnanto Yogyakarta: PSW IAIN Sunan Kalijaga.

Ilyas, Hamim. 2004. Studi Kitab Tafsir. Yogyakarta: Teras.

Kadarusman. 2005. Agama, Relasi Gender dan Feminesme. Yogyakarta: Kreasi Wacana.

Mernissi, Fatima dan Riffat Hassan. 1995. Setara di Hadapan Allah. Yogyakarta: LSPPA Yayasan Prakarsa.

Moleong, Lexy J. 2007. Metodologi Penelitian Kualitatif. Bandung: PT. Remaja Rosdakarya.

Nadjib, Ala'I. "Faminis Muslim Indonesia (Aliran Pemikiran Antara 1990-2000)”, Research Paper, 3:2, 2008.

Shihab, M. Quraish. 1992. Membumikan Al-Qur'an, Fungsi dan Peran Wabyu dalam Kebidupan Masyarakat. Bandung: Mizan.

al-Shabuni, Muhammad Ali. 1981. Tafsir Ayat al-Ahkam. Jilid 1. Damsyik: Maktabah al-Ghazali.

Umar, Nasaaruddin. 1999. Argumen Kesetaraan Gender Perspektif Al-Qur'an. Jakarta Selatan: Paramadina.

Umar, Nazaruddin dkk. 2002. Rekonstruksi Metodologis Wacana Kesetaraan Gender Dalam Islam. 
Yogyakarta: Pustaka Pelajar.

Wadud, Aminah. 2001. Qur'an Menurut Perempuan, Meluruskan Bias Gender dalam Tradisi Tafsir. Jakarta: PT Serambi Ilmu Semesta.

Watt, W. Montgomery. 1968. Islamic Political Thought. North America: Edingburgh University Press.

al-Zarqani, Muhammad 'Abd al-'Azhim. 1988. Manabil al-Irfan fi Ulum al-Qur'an, Juz. I, Beirut: Dar al-Fikr. 